\title{
Editorial
}

\section{Huntington's Disease in Popular Culture: A Brief Historical Perspective}

\author{
Alice Wexler* \\ Santa Monica, California, USA
}

In Ruth Rendell's 1988 London mystery House of Stairs, the narrator suggests a startling sea change in the world of Huntington's disease (HD). "The newspapers and television and magazines have been full of Huntington's lately," she observes. "Huntington's has become a fashionable disease, displacing multiple sclerosis and even schizophrenia in the public's curiosity." [1]. She refers, no doubt, to the publicity surrounding the discovery of a genetic marker for HD in 1983 and the beginning of presymptomatic genetic testing three years later [2]. The start of the Human Genome Project in 1990 and the identification of the expanded Huntingtin gene in 1993 drew further attention to HD [3].

Considering that many people get their medical information from popular culture, it is useful to consider how HD has been portrayed on television and also in novels such as House of Stairs [4]. Why did the disease suddenly start to appear at this time when it was largely absent before? What aspects were emphasized? How accurate were fictional and dramatic portrayals? What societal attitudes toward the disease were revealed? How did presentations of HD differ from those of other neurological, psychiatric, and/or genetic disorders? Did representations change over time as biomedical knowledge of HD advanced?

Prior to the 1980 s, characters with HD or at risk rarely appeared in fiction or in television dramas. When they did, they were minor figures, portrayed inaccurately, like Tony Polar in Valley of the Dolls (1966) [5]. Or they were patients in a single episode of a medical drama, as in Marcus Welby, M.D. (1970) [6]. But starting in the 1980 s, persons at risk began to

*Correspondence to: Alice Wexler, PhD, 1930 Ocean Avenue, \#315, Santa Monica, California 90405, USA. E-mail: arwexler@ ucla.edu. appear as protagonists in stories and TV series that often portrayed them with considerable empathy and realism. Unlike other diseases such as Alzheimer's disease that were shown through characters living with the illness, HD was distinctive in appearing primarily through a character at risk. Many of these at risk characters struggled with anxiety, depression, and the dread of becoming ill, as for example in House of Stairs: "Huntington's chorea were words I repeated to myself if not every day of my life, almost as often," the narrator Elizabeth Vetch tells us. Anytime she stumbles or drops something, "the feeling is always inescapable that this may be it, this time it is no ordinary tiredness but the early warning in itself [1]."

Not surprisingly, the presymptomatic gene test loomed large in a number of TV dramas and novels, with two television series featuring major characters trying to decide whether to learn their genetic status. "Everwood" (set in a small Colorado town in the early 2000s), shows high school senior Hannah, whose father has HD, going by herself (not standard practice) to see a social worker (not a genetic counselor, as would typically be the case). In this episode the social worker nicely explains the complexity of the testing process and the profound consequences of the choice though another episode subtly trivializes the impact by equating it with a much less significant discovery (i.e., with Hannah's best friend learning that her boyfriend has got another girl pregnant) [7].

In perhaps the most well known and complex television depiction of a character at risk, the medical drama "House" showed "Thirteen" (Dr. Remy Hadley) as a secretive, sardonic, but talented young staff physician working under Dr. Gregory House at a Princeton, New Jersey hospital. A number of episodes involve a verbal tug of war over the genetic test between Thirteen 
and the brilliant but sometimes abusive House, whose behavior on this issue goes against all accepted protocols. Suspecting Thirteen may be developing HD symptoms, House taunts her with being "in denial" and afraid to get the genetic test, which Thirteen resists, saying "when you run out of questions, you run out of hope." But Thirteen also violates rules when she eventually tests herself and, all alone, learns she carries the abnormal gene. More realistic is her (temporarily) reckless behavior after getting this result and her guilty memories of her HD-affected mother. Still, through many twists and turns of the plot, House continues to respect Thirteen as a physician no matter what else is going on in her life. She may be fatalistic, but she is also feisty. "You want to make sure your life matters," she tells one of her patients. "I don't want to be just tightening bolts and following instructions. I want something to be different because of me [8]." Above all she is a complicated, sometimes contradictory figure whose behavior and personality cannot be reduced to the disease.

Set in Paris rather than Princeton, Emilie Hermant's 2009 Reveiller l'aurore [Awakening the Dawn] features a narrator, Alice Rivieres, who unlike Thirteen felt obliged to get the test from the moment it became available. The novel beautifully portrays her fury and depression on learning she carries the expanded gene, not so much because of this result as because of the closed narrative of "deterioration" in which it is framed. After months of complete withdrawal and grief, Alice begins a series of healing conversations with Tahitidouche, her container of bath gel whom she imagines as her interlocutor. Eventually the piano music of Schumann, coming over the radio, breaks through her paralysis, opening up "miniscule points of light that flicker slightly in the night, signaling a far off city at the edge of the sea." Together with "Tahiti," she embarks on a journey, both figurative and literal, toward a place of creativity and hope [9].

As in Reveiller l'aurore, the social stigma surrounding HD is a theme effectively woven through many portrayals, typically conveyed through the at risk character's feeling of being devalued and the fear-and sometimes experience-of rejection. For example, when Isabel da Costa in Erich Segal's 1985 novel Prizes learns she is at risk for HD, she suddenly feels like a "leper," a woman with "an appalling heritage" whom no rational person would want to marry [10]. Alice Rivieres mourns that "no one could love a girl like me. I am not normal, I am going to disappear." The female narrator in Joanna Scott's 1994 short story "Tumbling," states straightforwardly that "the few men
I dated after my daddy's death were tourists since the locals wouldn't have me." As she puts it, "give a decent girl two-to-one odds [not correct] that she is carrying a time-bomb, and even the most desperate romantics will keep their distance [11]."

In fact, a number of female characters at risk are portrayed as alone or involved in difficult romantic relationships while their male counterparts usually have supportive partners. In some stories, the protagonist herself rejects love out of a desire to avoid putting a partner in the position of seeing her "deterioration" and having to care for her through a long illness, as in Jennifer duBois's A Partial History of Lost Causes, published in 2012 [12]. In others, her choices turn out badly, as in House of Stairs. Or she engages in promiscuous behavior, as in "House," although Thirteen eventually forms a satisfying relationship with another woman. And Isabel da Costa's boyfriend sticks by her despite her feelings of being "a genetic time bomb."

Secrecy and the difficulty of talking about HD in the family — or even learning much about it — is another salient theme, often presented as an important cause of the main character's unhappiness and sense of isolation. In many stories HD is at the heart of a family mystery, as in Nancy Werlin's 2004 young adult novel Double Helix, which addresses the themes of kids overhearing parents discussing HD and the difficulties of disclosure to friends as well [13]. Steven T. Seagle's 2004 graphic novel It's a Bird also centers around the efforts of the protagonist, a writer for Superman comics, to talk about HD with his parents, who tried to protect their children by keeping the disease hidden and who struggle with shame and guilt themselves [14]. Sometimes secrecy is shown as a strategy of self-protection, especially in relation to marriage and childbearing: the von Kleist brothers in Kurt Vonnegut's 1985 sci-fi novel Galapagos keep their risk secret out of a desire to protect both their relatives and themselves. For "if it had been generally known that the brothers might transmit Huntington's to their offspring, all the von Kleists would likely have found it difficult to make good marriages..." [15].

How accurate were portrayals of HD symptoms and etiology? Fiction and television dramas tended to emphasize the horrors of HD- "one of the real "nasties" - no doubt as much for dramatic effect as for an attempt to be realistic [10]. Most correctly noted the 50-50 risk (some spelled out autosomal dominant inheritance) and the fact that HD is a "disease of the brain" that affects behavior and causes involuntary movements, described variously as "dancing," 
"jerking," "twitching," "spasms," "fidgeting," "lurching" and so forth. Some authors also alluded to atypical symptoms such as "hallucinations" and "delusions," using popular language such as "going crazy" or becoming "insane" or "madness" to describe cognitive and mood disturbances although these terms are inappropriate. In its portrayal of the thuggish Baxter, a man with the slight choreic movements of early HD, Ian McEwan's 2008 bestseller Saturday plays on familiar stereotypes of the person with HD as violent and destructive and the person with disabilities as a villain. As Nancy Wexler and Michael Rawlins have shown, the surgeon-narrator in this novel, Henry Perowne, views Baxter almost as if he were a monster, reducing him to the sum of his symptoms and implying that all his bad actions can be attributed to his HD [16-18].

Nonetheless, as medical knowledge has advanced and HD and disability awareness have increased, the portrayal of HD has generally become more realistic and multifaceted, with characters who respond proactively despite the frequent mantras "untreatable and incurable" and "nothing to be done." For example "House" shows Thirteen enrolled in a clinical drug trial. Pierre Tardival, the protagonist of Robert Sawyer's 1997 sci-fi mystery Frameshift, attends an HD support group. A genetics researcher at the University of California, Berkeley, Tardival is a man with 79 CAG repeats (which should have given him juvenile HD actually). He marries and has a child through in vitro fertilization and preimplantation genetic diagnosis. He also fights genetic discrimination while uncovering a conspiracy against people with disabilities. Even as his symptoms emerge, he does genetics research for as long as he is able [19].

The American protagonist of A Partial History of Lost Causes also goes on a quest inspired by her awareness of carrying the aberrant HD gene. After her chess-playing father dies with HD, she decides to pursue his haunting question: "how one proceeds in the face of catastrophe, how one gracefully executes the closing moves of a doomed game..." In St. Petersburg, Russia in 2006, she becomes the confidante of a former chess champion turned opposition political leader, an idealistic man who runs for president against Vladimir Putin with no hope of winning and whose life, under constant death threats, helps her find value in her own [12].

If A Partial History and Frameshift employ the motif of racing against time before catastrophe strikes, Octavia Butler's sci-fi short story "The Evening and the Morning and the Night" challenges the notion of "catastrophe" altogether. It is also one of the earli- est HD stories, published in 1987 by the only African American author in the group. In this tale, the young protagonist Lynn carries two copies of the gene for what Butler calls Duryea-Gode disease or DGD, a fictional disorder that combines features of HD, PKU, and Lesch-Nyan disease. Lynn knows it is "only a matter of when: now or later." However in Butler's vision, "DGDs" have talents favorable to aesthetic creation, if only they can live in a supportive community that constrains their self-destructive tendencies. When Lynn and her boyfriend, another double DGD, visit such a community, they see the possibilities. As a female double DGD, Lynn learns she has additional gifts that make her especially sought after as a resident [20]. In this story, according to literary scholar Gerry Canavan, the disease "need not be understood solely as a tragic, ultimately meaningless fall from grace, but [as part of] a fully human life that can retain its own dignity and vitality despite hardship" [21]. It is interesting that Butler was one the few writers to imagine a scenario in which HD could be prevented or cured. In her 1988 trilogy Adulthood Rites, she describes one character inducing in another "an enzyme that turned off the Huntington's gene," much like the process of gene silencing today [22].

In conclusion, these stories and TV dramas offer a window onto popular perceptions of HD disease during the years of the Human Genome Project and the decade after. They suggest both the persistence of eugenic assumptions and the emergence of new ways of thinking about disability. Above all, by speaking about HD, they help dispel the silence and shame that have long added to the suffering caused by this disease. The fact that HD is now well enough known to be part of the backstory for the award-winning twentyfirst century TV series "Breaking Bad" suggests how much has changed [23].

Hopefully in the future we will see more accurate portrayals of genetic testing for $\mathrm{HD}$ and a greater diversity of HD characters (most of the current ones are of predominantly European ancestry and live in North America or Western Europe). We will see characters managing the illness in the way that, say, the actor Michael J. Fox manages his Parkinson's disease; stories illuminating the social conditions that add immeasurably to the burdens of HD and dramas that imagine new social environments to enhance lives with HD. By opening up conversations about HD, these forms of popular culture offer a valuable addition to the physician's armamentarium and an important resource for medical and science students, clinicians, HD families, and the general public alike. 


\section{ACKNOWLEDGMENTS}

I wish to acknowledge the Center for the Study of Women, University of California, Los Angeles, for supporting this project. I am also grateful to Vicki Wheelock, Alex Osmond, and Emilie Hermant for introducing me to three of the novels included here.

\section{HUNTINGTON'S DISEASE IN ENGLISH AND FRENCH LANGUAGE FICTION}

1966. Jacqueline Susann. Valley of the Dolls. New York: Grove Press.

1985. Kyle Duncan. The Dancing Men. Glasgow: Fontana/Collins.

1985. Kurt Vonnegut. Galapagos. New York: Delacorte.

1987. Octavia Butler. "The Evening and the Morning and the Night." In Bloodchild and Other Stories. 2nd Ed. New York: Seven Stories Press; 2005.

1988. Barbara Vine. [Ruth Rendell]. House of Stairs. New York: Harmony Books.

1993. Joanna Scott “Tumbling.” In Various Antidotes. New York: Holt.

1994. Erich Segal. Prizes. New York: Ballantine Books.

1996. Jill Rubalcaba. St. Vitus Dance. New York: Clarion Books.

1997. Robert J. Sawyer. Frameshift. New York: Tom Doherty Associates.

2001. Diane Tullson. Saving Jasey. Victoria, Canada: Orca Book Publishers.

2004. Steven T. Seagle and Teddy Kristiansen. It's a Bird. New York: DC Comics.

2004. Nancy Werlin. Double Helix. New York: Penguin.

2005. Ian McEwan. Saturday. London: Jonathan Cape.

2009. Emilie Hermant. Reveiller l'Aurore. Paris: Seuil.

2012. Jennifer duBois. A Partial History of Lost Causes. New York: Dial Press.

\section{REFERENCES}

[1] Rendell R [Vine B] House of Stairs. New York: Harmony Books; 1988.

[2] Nelson H. "Genetic Disease 'Marker' Identified. Could Lead toward Test to Predict Huntington's Disease" Los Angeles Times. November 10, 1983; Lawrence K.
Altman. "Researchers Report Genetic Test Detects Huntington Disease." New York Times. November 9, 1983; Harold M. Schmeck. "Fetal Gene Test Can Now Find Many More Genetic Flaws.” New York Times. March 11, 1986.

[3] Angier N. "Researchers Locate Gene That Triggers Huntington's Illness." New York Times, March 24, 1993.

[4] Reagan LJ, Tomes N, Treichler PA, editors. Medicine's Moving Pictures: Medicine, Health, and Bodies in American Film and Television. Rochester, New York: University of Rochester Press; 2007.

[5] Susann J. Valley of the Dolls. New York: Grove Press; 1966. Although this novel does not name Huntington's, references to "a brain illness," "sins of the father," and the fact that "the kind of condition he has is passed on" have led many readers to link Tony Polar's illness with HD. The 1967 film version of "Valley of the Dolls" does mention Huntington's.

[6] "Marcus Welby M.D." February 3, 1970: "Dance to No Music."

[7] Everwood. Season 3. Episode 10, "Need to Know." November 29, 2004. Episode 14, "Since You've Been Gone." February 7, 2005. Episode 15, "Surprise." February 14, 2005.

[8] "House." Season Four, 2007-2008: Episode 8, "You Don't Want to Know"; Episode 15, "House's Head"; Episode 16, "Wilson's Heart"; Season Five, 2008-2009: Episode 1, "Dying Changes Everything"; Episode 5, "Lucky Thirteen"; Episode 9, "Last Resort"; Episode 10, "Let Them Eat Cake", Episode 11, "Joy to the World"; Episode 12, "Painless"; Episode 14, "The Greater Good"; Season Six, "Help Me"; Season Seven, "The Dig."

[9] Hermant E. Reveiller l'aurore. Paris: Seuil; 2009.

[10] Segal E. Prizes. New York: Ballantine Books; 1995.

[11] Scott J. "Tumbling." In Various Antidotes. New York: Holt; 1993.

[12] Dubois J. A Partial History of Lost Causes. New York: Dial Press; 2012.

[13] Werlin N. Double Helix. New York: Penguin; 2004.

[14] Seagle ST, Kristiansen T. It's a Bird. New York: DC Comics; 2004

[15] Vonnegut K. Galapagos. New York: Delacorte; 1985.

[16] McEwan I. Saturday. London: Jonathan Cape; 2005.

[17] Wexler NS, Rawlins M. "Prejudice in a portrayal of Huntington's disease." The Lancet 2005. 24 September 36(9491): 1069-1070.

[18] Longmore PK. "Screening Stereotypes: Images of Disabled People.” Social Policy. Summer 1985.

[19] Sawyer RJ. Frameshift. New York: Tom Doherty Associates; 1997.

[20] Butler O. "The Evening and the Morning and the Night." 1987. In Bloodchild and Other Stories. 2nd Ed. New York: Seven Stories Press; 2005.

[21] Canavan G. "Life Without Hope? Huntington's Disease and Genetic Futurity.” Disability in Science Fiction. Representations of Technology as Cure. Edited by Kathryn Allan. New York: Palgrave MacMillan; 2013.

[22] Butler O. Adulthood Rites. New York: Warner Books; 1988

[23] Breaking Bad. 2008-2013. Created by Vince Gilligan. Season Four, Episode 10. "Salud." September 18, 2011. The protagonist Walter White explains to his son that his own father had died with Huntington's when he was very young, but his parents had him tested as a child (although testing children is against standard protocols) and learned that he, Walter, did not have the abnormal gene. Walter does not want his son to remember him in the way that he remembers his own dying father. 